\title{
PERSEPSI PENGRAJIN TERHADAP PENGEMBANGAN INDUSTRI RUMAH PANGGUNG DI DESA MOKOBANG KECAMATAN MODOINDING
}

\author{
Githa Claudia Waworuntu \\ Charles Reijaaldo Ngangi \\ Caroline Besty Diana Pakasi
}

\author{
Naskah diterima melalui Website Jurnal Ilmiah agrisosioekonomi@unsrat.ac.id $\quad$ : Jumat, 26 Juli 2019 \\ Disetujui diterbitkan \\ : Kamis, 24 Oktober 2019
}

\begin{abstract}
This study aims to examine how the craftsman's perception of the development of the stilt house industry in the village of Mokobang, Modoinding District, South Minahasa Regency. The research lasted for two months starting from February to April 2017 in Mokobang Village, Modoinding Sub-district, Minahasa Regency. The data used are primary data and secondary data. Primary data is data obtained from direct interviews with 50 respondents of stage home industry craftsmen who were chosen purposively. Interviews were conducted with the help of a questionnaire prepared previously and using a Likert Scale. Secondary data were obtained from the Mokobang Village Office and the internet. From the internet through Google searching to get articles from various journals related to research topics about the perception of craftsmen on the development of the stage home industry. The data obtained were analyzed using descriptive analysis and presented in a table. The results showed that the public perception of the development of the wooden stilt house industry in Mokobang Village, Modoinding Sub-district, South Minahasa Regency was classified in the good category, which was based on indicators of perception of the availability of wood raw materials, labor and knowledge about wood quality. ${ }^{*}$ eprm*
\end{abstract}

Keywords: perception, craftsman, development, stage home industry.

\begin{abstract}
ABSTRAK
Penelitian ini bertujuan untuk mengkaji bagaimana persepsi pengrajin terhadap pengembangan industri rumah panggung di Desa Mokobang Kecamatan Modoinding Kabupaten Minahasa Selatan. Penelitian berlangsung selama dua bulan mulai dari bulan Februari sampai April 2017 di Desa Mokobang Kecamatan Modoinding Kabupaten Minahasa. Data yang digunakan adalah data primer dan data sekunder. Data primer merupakan data yang diperoleh dari wawancara langsung pada 50 responden pengrajin industri rumah panggung yang dipilih secara sengaja (purposive sampling). Wawancara dilakukan dengan bantuan kuesioner yang disusun sebelumnya serta menggunakan Skala Likert. Data sekunder diperoleh dari Kantor Desa Mokobang dan intenet. Dari internet melalui google searching untuk mendapatkan artikel dari berbagai jurnal yang berkaitan dengan topik penelitian tentang persepsi pengrajin terhadap pengembangan industri rumah panggung. Data yang diperoleh dianalisis menggunakan analisis deskriptif dan disajikan dalam tabel. Hasil penelitian menunjukkan bahwa persepsi masyarakat terhadap pengembangan industri rumah panggung kayu di Desa Mokobang Kecamatan Modoinding Kabupaten Minahasa Selatan tergolong pada kategori baik, yang didasarkan pada indikator persepsi terhadap ketersediaan bahan baku kayu, tenaga kerja dan pengetahuan tentang kualitas kayu. ${ }^{* e p r m *}$
\end{abstract}

Kata kunci: persepsi, pengrajin, pengembangan, industri rumah panggung. 


\section{PENDAHULUAN}

\section{Latar Belakang}

Pembangunan di Indonesia sangat ditunjang oleh tumbuhnya berbagai jenis industri dengan berbagai jenis kegiatan. Dari segi fisik, yang mendukung pertumbuhan dan perkembangan industri, meliputi komponenkomponen lahan, bahan baku, sumber-sumber energi dan iklim dengan segala proses alamiahnya. Sedangkan dari segi manusianya meliputi komponen-komponen tenaga kerja, kemampuan teknologi, tradisi, keadaan politik, keadaan pemerintah , transportasi dan komunikasi, konsumen, pasar dan sebagainya sehingga menjadi barang yang bernilai bagi masyarakat.

Di Indonesia industri kerajinan terus mengalami perkembangan dan mendapat perhatian yang cukup besar dari pemerintah. Industri kecil merupakan salah satu strategi pembangunan masyarakat desa, sehingga perlu dikembangkan untuk meningkatkan kesempatan kerja dan merupakan bidang usaha yang menjadi tumpuan harapan masyarakat. Kerajinan rumah panggung merupakan salah satu jenis industri yang berkembang dalam kehidupan manusia. Industri kecil yang merupakan industri berbasis masyarakat diproduksi dan dikelola oleh masyarakat.

Kayu merupakan salah satu bahan baku yang memiliki manfaat yang sangat bernilai bagi manusia diantaranya sebagai bahan konstruksi, meubel, barang kerajinan, kayu bakar, peralatan rumah tangga dan lainnya. Dengan itu industri merupakan bagian dari proses produksi, bahanbahan industri diambil secara langsung maupun tidak langsung, kemudian diolah sehingga menghasilkan barang yang bernilai lebih bagi masyarakat (Iskandar, 2011). Bahan baku kayu bagi industri kerajian hampir tidak mempunyai batasan jenis dan ukuran, pengembangan usaha ini akan memberikan dampak positif terhadap efisiensi sumber daya alam.

Adanya sumber kayu yang sangat melimpah, pada zaman dahulu banyak rumah yang dibangun berbahan kayu, salah satu adalah Rumah Kayu Minahasa yang biasa dikenal dengan sebutan Wale atau Bale. Sebagian besar penduduk masyarakat Desa Mokobang Kecamatan Modoinding Kabupaten Minahasa Selatan memiliki keterampilan kerajian tangan dalam mengembangkan konstruksi bangunan rumah kayu (rumah panggung) yang saat ini pemasaran atau penjualannya telah sampai keluar daerah.

Seiring dengan perkembangan waktu dan teknologi penduduk mampu mengembangkan rangkaian produk rumah panggung yang desain dan dibangun dengan teknik modern tanpa menghilangkan unsur tradisional dari rumah panggung ini. Industri kerajinan rumah panggung ini merupakan aktivitas turun temurun yang merupakan warisan dari para pendahulu warga masyarakat setempat. Sudah menjadi tradisi bagi warga desa setempat untuk mewariskan pengetahuan mereka dalam membangun usaha rumah panggung ini kepada anak, cucu mereka, sehingga ketrampilan mereka dapat lestari.

Masyarakat di Desa Mokobang berpeluang untuk bisa mengembangkan usahanya lebih baik lagi dan lebih maju, sehingga akan berpengaruh pada tingkat penghasilan yang tinggi. Perlu diketahui bagaimana persepsi pengrajin terhadap pengembangan industri rumah panggung dan mengetahui juga tanggapan dari masyarakat untuk merespon dalam pengembangan industri rumah panggung, khususnya yang ada di Desa Mokobang Kecamatan Modoinding Kabupaten Minahasa.

\section{Pengertian Persepsi}

Persepsi merupakan sebuah proses yang hampir bersifat otomatik dan bekerja dengan cara yang hampir serupa pada masing masing individu, tetapi sekalipun demikian secara tipikal menghasilkan persepsi yang berbeda-beda (Slameto, 2003).

Persepsi masyarakat merupakan pengalaman tentang objek, peristiwa atau hubungan-hubungan yang diperoleh dengan menyimpulkan informasi dan menafsirkan pesan, dan persepsi adalah suatu proses yang kompleks dimana kita menerima dan menyadap inforrnasi dari lingkungan (Rakhmat, 2005). Persepsi adalah proses pemberian arti (cognitive) yang digunakan oleh seseorang untuk menafsirkan dan memahami dunia sekitarnya (Abduladjid, 1985). Persepsi berkaitan untuk mendapatkan pengetahuan khusus yang mencakup penafsiran terhadap orang, obyek atau tanda pada sudut pandang berdasarkan pengalaman seseorang yang dapat mempengaruhi perilaku atau pembentukan sikap seseorang. 
Menurut para ahli, persepsi dapat dikontrol melalui berbagai faktor stimulus dan pengaruh dari pengalaman masa lampau, motivasi dan sikap. Selain itu persepsi dapat di pandang berdasarkan faktor internal maupun eksternal.

Persepsi merupakan proses aktivitas seseorang dalam memberikan pesan, penilaian, pendapat, memahami, mengorganisir, menafsirkan yang memungkinkan individu melakukan penilaian terhadap suatu objek, situasi, peristiwa yang dapat memotivasi prilaku positif atau negatif.

\section{Faktor-faktor yang mempengaruhi persepsi}

1. Faktor internal

Faktor internal yang ada pada diri seseorang akan mempengaruhi bagaimana seseorang menginterpretasikan stimulus yang di lihatnya.
a. Pengalaman/pengetahuan,
b. Harapan (espectation)
c. Kebutuhan
d. Motivasi
e. Emosi
f. Budaya

2. Faktor eksternal

Adalah faktor yang melekat pada obyeknya, dan cici-ciri faktor eksternal yaitu ;

a. Perubahan intensitas

b. Pengulangan (repetition)

c. Sesuatu yang baru (novelty)

d. Sesuatu yang menjadi perhatian orang banyak.

\section{Pengertian Pengembangan Usaha}

Pengembangan adalah upaya pendidikan baik formal maupun non formal yang dilaksanakan secara sadar, berencana, terarah, teratur dan bertanggung jawab dalam rangka memperkenalkan, menumbuhkan, membimbing, mengembangkan suatu dasar kepribadian yang seimbang, utuh, selaras, pengetahuan, keterampilan sesuai dengan bakat, keinginan serta kemampuan-kemampuan, sebagai bekal atas prakarsa sendiri untuk menambah, meningkatkan, mengembangkan diri ke arah tercapainya martabat, mutu dan kemampuan manusiawi yang optimal serta pribadi mandiri (Wiryokusumo, 2011). Pengembangan memusatkan perhatiannya tidak hanya pada analisis kebutuhan, tetapi juga isuisu luas tentang analisis awal-akhir, seperti analisi kontekstual. Pengembangan bertujuan untuk menghasilkan produk berdasarkan temuan-temuan uji lapangan. (Sumarno, 2012). Pengembangan suatu usaha adalah tanggungjawab dari setiap pengusaha atau wirausaha yang membutuhkan pandangan ke depan, motivasi dan kreativitas (Anoraga, 2007).

\section{Rumusan Masalah}

Masalah dalam penelitian ini yaitu: Bagaimana persepsi pengrajin terhadap pengembangan industri rumah panggung di Desa Mokobang Kecamatan Modoinding Kabupaten Minahasa Selatan?

\section{Tujuan Penelitian}

Tujuan penelitian yaitu: untuk mengetahui persepsi pengrajin terhadap pengembangan industri rumah panggung di Desa Mokobang Kecamatan Modoinding Kabupaten Minahasa Selatan.

\section{Manfaat Penelitian}

Penelitian ini diharapkan dapat menambah wawasan bagi peneliti, pemerintah dan pihak terkait serta masyarakat di Desa Mokobang Kecamatan Modoinding Kabupaten Minahasa Selatan dalam peningkatan usaha pengembangan industri rumah panggung.

\section{METODE PENELITIAN}

\section{Waktu dan Tempat Penelitian}

Penelitian dilaksanakan di Desa Mokobang Kecamatan Modoinding Kabupaten Minahasa Selatan yang berlangsung selama 2 bulan mulai dari Bulan Februari 2017 sampai April 2017 mulai dari persiapan, pengambilan data sampai pada penyusunan laporan hasil penelitian.

\section{Metode Pengumpulan Data}

Metode pengumpulan data dilakukan dengan menggunakan data primer dan data sekunder. Data primer diperoleh dari wawancara langsung dengan responden menggunakan kusioner yang telah disiapkan dan data sekunder diperoleh dari Kantor Pemerintah Desa Mokobang Kecamatan Modoinding Kabupaten Minahasa Selatan. 


\section{Metode Pengambilan Sampel}

Metode Pengambilan sampel dilakukan dengan menggunakan metode Purposive Sampling (secara sengaja), yaitu suatu metode dimana sampel yang diambil dari populasi yang dipilih berdasarkan sengaja dipilih/diambil pelaku usaha yaitu pengusaha dan pengrajin. Sampel dalam penelitiaan ini berjumlah 50 responden.

\section{Pengukuran Variabel}

Variabel yang dikaji dalam penelitiaan ini adalah:

1. Karakteristik responden yang mencakup :
a. Jenis Kelamin (laki-laki/perempuan)
b. Umur (tahun)
c. Tingkat Pendidikan (SD, SLTP, SLTA dan Sarjana)
d. Pekerjaan sampingan/pekerjaan tambahan lainnya.

2.Persepsi masyarakat terhadap usaha rumah panggung, yang diukur sebagai berikut :

a. Pendapat atau tanggapan, yakni pandangan yang diberikan oleh pengrajin terhadap pengembangan industri rumah panggung.

b. Ketersediaan bahan baku kayu

c. Ketersediaan tenaga kerja

d. Pengetahuan tentang kualitas kayu

e. Peningkatan kesejahteraan masyarakat

\begin{abstract}
Analisis Data
Analisis data dalam penelitian ini yaitu analisis deskriptif yang setiap jawabannya menggunakan daftar tabel dan angka yang menggunakan skala likert (likert scale). Skala likert digunakan untuk mengukur sikap, pendapat, dan persepsi seseorang atau kelompok orang tentang fenomena seseorang (Soegiono, 1996 dan Sunyoto, 2014). Dalam skala likert, maka variabel yang diukur dijabarkan menjadi indikator variabel. Kemudian indikator tersebut dijadikan sebagai titik tolak untuk menyusun item-item instrumen yang dapat berupa pernyataan-pernyataan. Untuk mengukur persepsi masyarakat disusun 15 pernyataan dengan total responden 50 orang.
\end{abstract}

\section{HASIL DAN PEMBAHASAN}

\section{Deskripsi Rumah Panggung}

Rumah panggung merupakan rumah adat yang terbuat dari kayu, sudah berabad-abad lamanya digunakan sebagai rumah tinggal dan rumah ini telah teruji tahan gempa yang kerap kali digoncang gempa bumi karena letak geografis lingkaran gunung berapi aktif seperti Gunung Lokon di Tomohon dan Gunung Soputan di Minahasa Selatan.

Rumah panggung ini mempunyai karakteristik yang menjadi ciri khas yaitu dua tangga kembar di bagian depan rumah. Selain itu ornamen-ornamen dekoratif yang terdapat di rumah ini juga membuatnya menjadi sangat menarik, indah dan elegan bila dipandang jauh. Keunikan juga dari rumah panggung yang ada di Desa Mokobang adalah ketika ada rumah yang akan dibangun, masyarakat setempat bersamasama membantu bekerja atau kerja bakti biasanya yang dikenal dengan istilah mapalus. Mapalus ini sudah menjadi tradisi bagi masyarakat Desa Mokobang ketika mereka mendirikan rumah kayu atau dengan kata lain "bakancing".

Berbagai jenis ukuran rumah panggung yang disediakan di desa ini dan yang paling banyak adalah ukuran 4x6 m, 7x8 m dan 9x8 bahkan ada yang 10x12 meter persegi. Harga jual jika dipasarkan dihitung berdasarkan $1 \mathrm{~m}$ persegi yakni sebesar Rp 1.500.000. Lama pekerjaan tergantung besar dan luasnya rumah panggung sekitar 2 minggu sampai 1 bulan. Upah untuk pekerja dibayar per hari dengan perincian: Kepala Tukang (Kepala Bas) Rp 150.000/hari dan tukang biasa Rp 100.000/hari bekerja dimulai jam 08.00 sampai jam 17.00 ( jam 5 sore).

Dalam hal ini nilai ekonomi, sosial dan budaya masyarakat Desa Mokobang masih dan sudah melekat pada masyarakat. Adanya pengembangan industri khususnya industri rumah panggung, maka persepsi masyarakat sangat penting agar dapat menumbuhkan komunikasi aktif, sehingga dapat meningkatkan industri rumah panggung yang ada di Desa Mokobang.

\section{Karakteristik Responden}

\section{Umur Responden}

Karakteristik responden menurut umur mempengaruhi kemampuan seseorang dalam melakukakan aktivitas maupun konsep berpikir. Responden yang berumur muda tentunya memiliki kondisi fisik lebih kuat dibandingkan dengan responden yang berumur tua. Komposisi umur responden dalam penelitian ini di sajikan pada Tabel 1. 
Tabel 1. Responden menurut Umur

\begin{tabular}{llcr}
\hline No & Umur (Tahun) & Jumlah (orang) & Persentase (\%) \\
\hline 1. & $18-28$ & 7 & 14 \\
2. & $29-39$ & 16 & 32 \\
3. & $40-50$ & 17 & 34 \\
4. & $50>$ & 10 & 20 \\
\hline & Jumlah & 50 & 100 \\
\hline
\end{tabular}

Sumber: Data Primer, 2018

Tabel 1 menunjukkan bahwa jumlah responden terbanyak berada pada interval umur 40-50 tahun dan selanjutnya pada interval umur 29-39 tahun, dan yang paling sedikit responden yang berada pada interval pada umur 18-28 tahun.

\section{Pekerjaan Responden}

Jenis pekerjaan sangat mempengaruhi kesejahteraan masyarakat untuk bertahan hidup, masing-masing masyarakat memiliki pekerjaan yang berbeda-beda untuk memenuhi kebutuhan keluarganya setiap hari. Dapat di lihat pada Tabel 2.

\begin{tabular}{cccc}
\multicolumn{5}{c}{ Tabel 2. Responden Menurut } & Pekerjaan \\
\hline No & Pekerjaan & Jumlah (orang) & Persentase $(\%)$ \\
\hline 1. & Tukang Kayu & 22 & 44 \\
2. & Petani & 13 & 26 \\
3. & PNS & 4 & 8 \\
4. & Mahasiswa & 8 & 16 \\
6. & Swasta & 3 & 6 \\
\hline & Jumlah & 50 & 100 \\
\hline
\end{tabular}

Sumber: Data Primer, 2018

Tabel 2 menunjukkan bahwa dalam penelitian ini terdapat 7 kategori jenis pekerjaan dari responden, yaitu tukang kayu, petani, pegawai negeri sipil, mahasiswa, swasta. Kategori tukang kayu dan petani merupakan jenis pekerjaan terbanyak dari responden yaitu $70 \%$, dan mahasiswa sebanyak 8 orang 16 persen dan jenis pekerjaan swasta sebanyak 6 persen. Sedangkan jenis pekerjaan yang paling sedikit yaitu pegawai negeri sipil dan swasta.

\section{Jenis Kelamin}

Adapun klasifikasi responden berdasarkan jenis kelamin di Desa Mokobang Kecamatan Modoinding Kabupaten Minahasa Selatan, dapat dilihat pada Tabel 3.

Tabel 3. Jumlah Responden Menurut Jenis Kelamin

\begin{tabular}{llcr}
\hline No & Jenis Kelamin & Jumlah (orang) & Persentasi (\%) \\
\hline 1. & Laki-laki & 34 & 68 \\
2. & Perempuan & 16 & 32 \\
\hline & Jumlah & 50 & 100 \\
\hline
\end{tabular}

\section{Tingkat Pendidikan}

Pendidikan yang dimiliki oleh seseorang akan membedakan orang tersebut dengan mereka yang tidak memiliki pendidikan. Pendidikan dapat diperoleh secara formal seperti di bangku sekolah maupun formal seperti kursus atau pelatihan. Demikian halnya dengan responden di Desa Mokobang Kecamatan Modoinding Kabupaten Minahasa Selatan, dapat dilihat pada Tabel 4.

Tabel 4. Responden Menurut Tingkat Pendidikan

\begin{tabular}{llcr}
\hline No & Tingkat Pendidikan & Jumlah (orang) & Persentase $(\%)$ \\
\hline 1. & SD & 7 & 14 \\
2. & SMP & 6 & 12 \\
3. & SMA & 23 & 46 \\
4. & Perguruan Tinggi & 14 & 28 \\
\hline & Jumlah & 50 & 100 \\
\hline
\end{tabular}

Sumber: Data Primer, 2018

\section{Persepsi Masyarakat}

\section{Pengembangan Masa Depan Industri Rumah Panggung}

Masyarakat mempunyai harapan ke depan menjadi sangat lebih baik dalam pengembangan industri rumah panggung. Hal ini di Desa Mokobang Kecamatan Modoinding Kabupaten Minahasa Selatan, jika dilihat sekarang ini dalam pengembangan industri rumah panggung sudah semakin banyak masyarakat untuk membangun rumah kayu. Dapat dilihat pada Tabel 5.

Tabel 5. Persepsi terhadap Pengembangan Masa Depan Industri Rumah Panggung

\begin{tabular}{|c|c|c|c|c|}
\hline $\begin{array}{l}\text { Alternatif } \\
\text { Jawaban }\end{array}$ & Skor & $\begin{array}{l}\text { Jumlah } \\
\text { (orang) }\end{array}$ & Persentase (\%) & $\begin{array}{l}\text { Total } \\
\text { Skor }\end{array}$ \\
\hline Baik & 3 & 40 & 80 & 120 \\
\hline Ragu-ragu & 2 & 10 & 20 & 20 \\
\hline Tidak baik & 1 & - & - & - \\
\hline Total & & 50 & 100 & 140 \\
\hline
\end{tabular}

Sumber: Data Primer, 2018

Tabel 5 menunjukkan bahwa $80 \%$ responden setuju dengan pertanyaan masa depan industri rumah panggung akan menjadi sangat baik dalam pengembangannya. Sedangkan sisanya sebanyak $20 \%$ responden masih ragu-ragu dengan pernyataan tersebut. Total skor yang diperoleh dari 50 responden pada indikator pernyataan nomor satu ini adalah sebesar 140. Angka indeks persepsi masyarakat mengenai pernyataan satu yaitu : $140 / 150 \mathrm{x}$ $100 \%=93,33 \%$, sehingga nilainya tertolong 
tinggi karena masyarakat Desa Mokobang Kecamatan Modoinding Kabupaten Minahasa Selatan banyak berpendapat baik terhadap pengembangan industri rumah panggung.

Pengembangan industri rumah panggung akan menjadi motivasi yang sangat besar bagi masyarakat untuk tetap mengolah dan mengembangkan industri ini karena saat ini industri rumah panggung adalah salah satu pendapatan yang sangat menguntungkan perekonomian keluarga bahkan masyarakat. Dapat dilihat pada Tabel 6.

\section{Pengembangan Industri Rumah Panggung menjadi Motivasi bagi Masyarakat}

Tabel 6 menunjukkan bahwa 86\% responden setuju pengembangan industri rumah panggung akan menjadi motivasi bagi masyarakat sedangkam $14 \%$ responden menjawab ragu-ragu dengan pernyataan ini. Total skor yang diperoleh dari 50 responden pada pernyataan dua ini sebesar 143. Angka indeks persepsi masyrakat mengenail pernyataan dua yaitu : $143 / 150 \times 100=$ 95,33\% sehinggan interprestasi nilainya tertolong tinggi karen dengan pengembangan industry rumah panggung memberikan motivasi yang sangat besar.

Tabel 6. Persepsi terhadap Pengembangan Industri Rumah Panggung menjadi motivasi bagi masyarakat

\begin{tabular}{|c|c|c|c|c|}
\hline $\begin{array}{l}\text { Alternatif } \\
\text { Jawaban }\end{array}$ & Skor & $\begin{array}{l}\text { Jumlah } \\
\text { (orang) }\end{array}$ & $\begin{array}{c}\text { Persentase } \\
(\%)\end{array}$ & $\begin{array}{l}\text { Total } \\
\text { Skor }\end{array}$ \\
\hline Setuju & 3 & 43 & 86 & 129 \\
\hline Ragu-ragu & 2 & 7 & 14 & 14 \\
\hline Tidak & 1 & - & - & - \\
\hline \multicolumn{5}{|l|}{ Setuju } \\
\hline \multicolumn{2}{|c|}{ Total } & 50 & 100 & 143 \\
\hline
\end{tabular}

Sumber: Data Primer, 2018

Masyarakat memiliki pengetahuan kayu sebagai bahan baku utama banyak tersedia di Desa, masyarakat dan pekerjaan mengetahui bahan baku dari penjualan rumah kayu , masyarakat melakukan pemotngan pohon tetapi menanam kembali 100 pohon dan itu sudah menjadi budaya di desa. Kayu adalah hal penting dalam pembuatan rumah panggung jadi masyarakat memelihara dan melindungi pohon serta menanamnya agar dimasa mendatang kayu tidak puna (Tabel 7).

\section{Ketersediaan Bahan Baku Utama}

Tabel 7 menunjukkan bahwa $84 \%$ responden setuju dengan pernyataan. Sedangkan sisanya sebanyak $14 \%$ responden masih ragu-ragu dengan pernyataan tersebut.

Tabel 7. Persepsi Masyarakat tentang Bahan Baku Utama

\begin{tabular}{lcccc}
\multicolumn{5}{c}{ banyak tersedia di Desa } \\
\hline $\begin{array}{l}\text { Alternatif } \\
\text { Jawaban }\end{array}$ & Skor & $\begin{array}{c}\text { Jumlah } \\
\text { (orang) }\end{array}$ & $\begin{array}{c}\text { Persentase } \\
(\%)\end{array}$ & $\begin{array}{c}\text { Total } \\
\text { Skor }\end{array}$ \\
\hline Tersedia & 3 & 42 & 84 & 126 \\
Ragu-ragu & 2 & 7 & 14 & 14 \\
Tidak Tersedia & 1 & 1 & 2 & 1 \\
\hline \multicolumn{2}{c}{ Total } & 50 & 100 & 141 \\
\hline Sumber: Data Primer & 2018 & & &
\end{tabular}

Total skor yang dari 50 responden pada indikator pernyataan ini adalah sebesar 141. Angka indeks persepsi masyarakat mengenai pernyataan ini, yaitu : 141/150 x $100 \%=94 \%$, sehingga nilainya tergolong tinggi karena masyarakat tau kayu banyak tersedia di desa.

\section{Tenaga Kerja Tukang Kayu}

Di desa ada banyak profesi diantaranya petani dan tukang. Tetapi ketika rumah panggung menghasilkan banyak pemasukkan ada profesi petani tidak beraktivitas sebagai petani lagi, mereka mengisi waktu untuk bekerja sebagai tukang kayu. Dapat di lihat pada Tabel 8.

\begin{tabular}{|c|c|c|c|c|}
\hline $\begin{array}{l}\text { Alternatif } \\
\text { Jawaban }\end{array}$ & Skor & $\begin{array}{l}\text { Jumlah } \\
\text { (orang) }\end{array}$ & Persentase $(\%)$ & Total Skor \\
\hline Tersedia & 3 & 46 & 92 & 138 \\
\hline Ragu-ragu & 2 & 4 & 8 & 8 \\
\hline Tidak Tersedia & 1 & - & - & - \\
\hline Total & & 50 & 100 & 146 \\
\hline
\end{tabular}

Hasil penelitian ini menunjukkan bahwa 92\% responden setuju dengan pernyataan tukang kayu banyak tersedia di desa. Sedangkan sisanya sebanyak $8 \%$ responden masih raguragu dengan pernyataan tersebut. Total skor yang di peroleh dari 50 responden pada indicator pernyataan tersebut adalah sebesar 146. Angka indeks persepsi masyarakat tahu untuk memilih kayu. Dalam pemilihan kayu masyarakat tahu memilih kayu yang terbaik dalam mendirikan rumah kayu. Sehinggan kayu yang digunakan adalah kayu yang berkualitas dan yang terbaik berdampak baik bagi kualitas dari rumah panggung. 


\section{Pengetahuan Masyarakat tentang kayu}

Tabel 9 menunjukkan bahwa 64\% responden setuju dengan pernyataan masyarakat tahu untuk memilih kayu tersedia di desa. Sedangkan sisanya sebanyak $16 \%$ responden masih ragu-ragu dan tidak setuju sebanyak $20 \%$ responden dengan pernyataan tersebut. Total skor yang diperoleh dari 50 responden pada indikator pernyataan ini adalah sebesar 122. Angka indeks persepsi masyarakat mengenai pernyataan ini, yaitu : $122 / 150 \times 100 \%=81,33 \%$, sehingga nilainya tergolong tinggi karena sebagian masyarakata tahu memilih kayu.

Tabel 9. Persepsi Masyarakat Tentang Pengetahuan Untuk Memilih Kayu

\begin{tabular}{lllll}
\hline $\begin{array}{l}\text { Alternatif } \\
\text { Jawaban }\end{array}$ & Skor & $\begin{array}{l}\text { Jumlah } \\
\text { (orang) }\end{array}$ & $\begin{array}{l}\text { Persentase } \\
(\%)\end{array}$ & $\begin{array}{l}\text { Total } \\
\text { Skor }\end{array}$ \\
\hline Baik & 3 & 32 & 64 & 96 \\
Ragu-ragu & 2 & 8 & 16 & 16 \\
Tidak Baik & 1 & 10 & 20 & 10 \\
\hline \multicolumn{2}{c}{ Total } & 50 & 100 & 122 \\
\hline
\end{tabular}

Sumber: Data Primer, 2018

\section{Lahan yang digunakan sangat mendukung}

Lahan yang ada di desa tergolong banyak karena masih ada lahan-lahan kosong dan sangat berpotensi mendirikan rumah panggung. Di wilayah desa ini terdapat lahan yang datar dan tidak berbukit. Masyarakat mengambil keuntungan dari lahan ini untuk mendirikan rumah panggung. Hasil penelitian ini menunjukkan bahwa $88 \%$ responden setuju dengan pernyataan tersebut. Sedangkan sisanya sebanyak $8 \%$ responden masih raguragu dan tidak setuju sebanyak $4 \%$ responden dengan pernyataan tersebut.

Total skor yang diperoleh dari 50 responden pada indikator pernyataan tentang lahan yang digunakan adalah sebesar 142 . Angka indeks persepsi masyarakat mengenai pernyataan ini yaitu : $142 / 150 \times 100 \%=$ $94,66 \%$,sehingga nilainya tergolong tinggi karena lahan yang digunakan untuk mendirikan rumah panggung sangat mendukung. Masyarakat sering mengikuti sosialisasi dalam pembuatan rumah kayu sosialisasi ini sangat dibutuhkan masyarakat sehingga masyarakat bisa menambah keahlian dalam pembuatan rumah panggung.

\section{Perkembangan industri rumah panggung kayu di Desa Mokobang}

Perkembangan industri di era global ini sangat berpengaruh bagi kelangsungan hidup masyarakat. Industri-industri yang ada baik industri kecil, menengah, atau besar menjadi peluang masyarakat untuk mengantungkan hidup mereka pada industri tersebut. Dalam hal ini melihat perkembangan industri rumah panggung di Desa Mokobang Kecamatan Modoinding Kabupaten Minahasa Selatan.

Perkembangan industri rumah kayu ini sudah mulai meningkat, hal ini di buktikan dengan harga jual rumah kayu dan tingkat penjualannya sangat pesat, memperlihatkan bahwa industri rumah kayu di Desa Mokobang Kecamatan Modoinding Kabupaten Minahasa Selatan sangat menguntungkan masyarakat dengan harga jual tinggi, menguntungkan juga bagi masyarakat sekitar untuk mendapatkan pekerjaan sehingga bisa membantu masyarakat untuk mengurangi angka pengangguran, karena industri rumah panggung dapat membuka lapangan pekerjaan.

Minat masyarakat luar terhadap industri rumah kayu di Desa Mokobang Kecamatan Modoinding Kabupaten Minasaha Selatan di karenakan oleh beberapa faktor pendukung yaitu yang utama adalah kualitas kayu yang baik serta model rumah panggung yang inovatif dan menarik, kayu yang dipakai industri rumah kayu adalah kayu milik pribadi yang ditebang dari perkebunan dan memiliki teknik tertentu dalam pengolahannya.

Industri rumah panggung yang ada di Desa Mokobang Kecamatan Modoinding Kabupaten Minahasa Selatan memiliki manfaat yaitu bermanfaat untuk pengolahan rumah kayu sehingga industri rumah panggung sangat tepat dan strategis untuk mendirikan rumah kayu sangat mendukung. Persepsi yang ada pada masyarakat di Desa Mokobang Kecamatan Modoinding Kabupaten Minahasa Selatan terhadap pengembangan industri rumah panggung atau rumah kayu sangat baik. 


\section{KESIMPULAN DAN SARAN}

\section{Kesimpulan}

Hasil penelitian menunjukkan bahwa persepsi masyarakat terhadap pengembangan industri rumah panggung kayu di Desa Mokobang Kecamatan Modoinding Kabupaten Minahasa Selatan tergolong kategori baik, berdasarkan indikator persepsi. Hal ini menunjukkan bahwa dalam pengembangan industri rumah panggung dapat memberi peningkatan ekonomi bagi masyarakat, karena ketersediaan bahan baku yang sangat mendukung dan sumber daya manusia sebagai keterampilan dalam mengembangkan industri rumah panggung.

\section{Saran}

Bagi masyarakat Desa Mokobang Kecamatan Modoinding Kabupaten Minahasa Selatan, demi menjaga kualitas rumah panggung kayu, maka teknologi yang digunakan juga harus tetap disesuaikan dan juga menjaga ketersediaan bahan baku rumah panggung sambil tetap menjaga kualitas kayu.

\section{DAFTAR PUSTAKA}

Abduladjid. 1985. Pola Partisipasi Masyarakat Pedesaan Dalam Pembangunan Pertanian Berencana. Orba Sakti. Bandung.

Anoraga Pandji, 2007. Pengantar Bisnis. Pengelolaan Bisnis Dalam Era Globalisasi. Jakarta: Rieneka Cipta.

Iskandar, Wiryokusumo. 2011. Dasar-dasar Pengembangan Usaha Kerajinan Industri. Jakarta: Bumi Aksara. 